Transportation Research Forum

Transportation Infrastructure Implications of Development of a Cellulosic Biofuels Industry for Indiana

Author(s): Wallace E. Tyner and Craig W. Rismiller

Source: Journal of the Transportation Research Forum, Vol. 49, No. 1 (Spring 2010), pp. 95-112

Published by: Transportation Research Forum

Stable URL: http://www.trforum.org/journal

The Transportation Research Forum, founded in 1958, is an independent, nonprofit organization of transportation professionals who conduct, use, and benefit from research. Its purpose is to provide an impartial meeting ground for carriers, shippers, government officials, consultants, university researchers, suppliers, and others seeking exchange of information and ideas related to both passenger and freight transportation. More information on the Transportation Research Forum can be found on the Web at www.trforum.org. 


\title{
Transportation Infrastructure Implications of Development of a Cellulosic Biofuels Industry for Indiana
}

\author{
by Wallace E. Tyner and Craig W. Rismiller
}

Development of a cellulosic biofuels industry in biomass-rich states such as Indiana would cause substantial impacts on road infrastructure. This research estimated the infrastructure impacts of cellulosic biofuel production using three Indiana cellulosic facility sites. Following are key results:

- Average loaded vehicle trip miles (VTM) are projected to be 101 to 583\% higher per gallon of cellulosic biofuel capacity compared to the VTM per gallon of capacity for grain-based ethanol.

- Average ton-miles per gallon of capacity for cellulosic biofuel production is projected to be 4 to $255 \%$ higher compared to the average ton-mile per gallon of capacity for grainbased ethanol.

\section{INTRODUCTION}

Since 2004, ethanol production capacity in the United States has increased drastically; from 3.1 billion gallons per year (BGY) in 2004 to a January 2009 capacity of 10.6 BGY (Renewable Fuels Association 2009). Currently, almost all of the ethanol produced in the United States stems from ethanol fermented from corn.

Cellulosic biofuels are gaining attention as a possible solution to decrease our dependency on foreign oil and produce a cleaner-burning fuel while not significantly affecting the price of agricultural commodities. The key distinction between grain-based ethanol and cellulosic biofuel production is that the cellulosic production can utilize any organic material to produce biofuels, namely wood wastes, corn stover or switchgrass. Two processes, biochemical and thermochemical production, are both advanced cellulosic production methods that likely will be utilized in the United States. Though both of the advanced biofuel production pathways hold promise, there are currently no commercial-scale cellulosic plants producing ethanol or under construction in the United States.

If a commercial cellulosic industry develops, the industry will face unique logistical issues compared to the established grain-based ethanol industry. Contrary to the rapid plant growth witnessed in the grain based ethanol industry, the cellulosic industry will likely develop at a slower pace as technology emerges. Increased planning will allow investors to select plant sites that minimize transportation costs of both feedstuffs and the finished biofuel product. The cellulosic biofuels industry will likely develop in Midwestern states like Indiana, where high levels of corn production produce a supply of unused corn stover. Unlike the grain-based industry, cellulosic facilities will likely rely solely on local materials for its feedstuff, thus increasing local truck traffic and the burden on the local road infrastructure. Rail will only be used to move the finished biofuel product as cellulosic plants will not likely produce a saleable byproduct that requires transportation.

This report is the first to fully examine the impacts that the cellulosic biofuel industry will have on Indiana roadways. Cellulosic biofuel plants will significantly increase demand for local trucks that will deliver locally produced biomass. This study will follow a framework similar to a 2008 publication by Quear that estimated the impacts of the grain-based ethanol industry on Indiana's infrastructure but will be modified to reflect the unique impacts that the cellulosic industry will impose (Quear 2008). The results from this study will be benchmarked against Quear's grain-based ethanol industry infrastructure impact results. In addition, this study will follow Brechbill and 
Tyner's methodology in using ArcGIS to establish supply curves for each of the analyzed cellulosic facilities (Brechbill et al. 2008).

The key objective of this study is to determine the impacts that inbound biomass transportation will have on the road infrastructure in terms of truckloads of biomass, average length of haul (LOH), total vehicle trip miles (VTM) and ton-miles. Specifically this study will predict the concentration and location of inbound trucks that will be used to carry the biomass needed for future large-scale cellulosic plants in Indiana.

\section{LITERATURE REVIEW}

This section provides a brief review of the major literature relevant to this analysis. Because cellulose-based biofuels do not yet exist commercially, the literature is limited, and some of it is speculative. However, there are useful studies from the grain ethanol industry and some early cellulose feedstock studies that we have drawn upon in developing this analysis.

For the cellulosic biofuel industry to develop in Indiana or any other state, the cellulosic facilities will need to have access to adequate supplies of biomass. A 2008 study addressed issues such as biomass production and transportation costs, biomass availability in Indiana, and developed biomass supply curves for three potential Indiana biomass power plants (Brechbill et al. 2008). The study reported that biomass transportation costs represent a significant portion of the total cost per ton that the cellulosic plant will incur for biomass. Each ton of biomass transported incurs a marginal transportation cost of approximately 28 cents per mile if using custom equipment (Brechbill et al. 2008). In addition to the marginal transportation cost, Brechbill and Tyner (2008) included a fixed cost of $\$ 1.15$ per ton which represents the labor expenses incurred for the loading and unloading of the biomass. Table 1 shows the estimated total transportation costs for transportation of biomass at varying distances. Brechbill and Tyner (2008) assume that transportation costs are linear, that is, there are no economies of distance for the transport component alone. It should be noted that the $\$ 2.53$ cost estimation for transporting biomass five miles includes the total \$1.15 expense incurred for loading and unloading the biomass.

Table 1: Transportation per Ton Cost with Custom Equipment

\begin{tabular}{lc}
\hline Distance from Cellulosic Plant & $\$$ per ton \\
\hline 5 Miles & $\$ 2.53$ \\
10 Miles & $\$ 3.92$ \\
15 Miles & $\$ 5.30$ \\
20 Miles & $\$ 6.69$ \\
25 Miles & $\$ 8.07$ \\
30 Miles & $\$ 9.46$ \\
35 Miles & $\$ 10.84$ \\
40 Miles & $\$ 12.23$ \\
45 Miles & $\$ 13.61$ \\
50 Miles & $\$ 15.00$ \\
\hline
\end{tabular}

Source: Brechbill and Tyner (2008)

The study also established estimates for the removal rates of corn stover based on sustainable levels. That is, the level at which corn stover can feasibly and sustainably be collected from the land. They established removal rates of $38 \%, 52.5 \%$ or $70 \%$ depending upon harvest and sustainability assumptions. Thus, the average sustainable removal rate is $53.5 \%$ with the worst-case removal rate being 38\%. These removals rates were used in conjunction with data from Perlack et al. (2005) and 
a farmer participation rate to establish the actual available biomass within each Indiana County.

Biomass supply curves were constructed for three potential Indiana biomass power plants using the Arc GIS mapping software. The study calculated the available biomass within each buffer distance by using county-level data on available crops and residues (Perlack et al. 2005) and varying removal and participation rates.

A somewhat similar study developed regional supply curves for crop residue cellulosic feedstocks for the eastern part of the state of Washington (Khachatryan et al. 2009). The authors used GIS techniques to estimate the residue available in the region. They then applied information on regional roads and speed limits to estimate transport times to a biomass conversion facility. The haul times were converted into transport cost and added to the farmgate residue cost to estimate supply curves for a cellulose conversion facility. Sensitivity analysis was done on diesel prices, as fuel cost was estimated to constitute about $46 \%$ of the ton mile transport cost.

Results of the Washington study were provided for a range of plant sizes, farmgate residue cost, and haul times. For example, a 55 million gal./yr. plant with farmgate residue cost of $\$ 25 /$ ton would require residue out to a 90-minute haul time or 60-mile haul distance. The delivered cost for the marginal ton was $\$ 30.51$, which yields a transport cost of $\$ 5.51 /$ ton. For a plant size of 117 million gal./yr. the delivered cost of the marginal ton was about $\$ 34.50$ under the same farm gate price of $\$ 25 /$ ton. The transport cost goes up considerably because the haul time increases to 150 minutes and the haul distance to 100 miles (both for the marginal ton). However, the transport costs from this study are considerably lower than the transport costs obtained in the Indiana study.

Another 2008 study (Quear 2008) focused on the impacts of grain-based biofuel expansion on the transportation infrastructure network in Indiana. The study included infrastructure impacts of both inbound and outbound transportation of corn, soybeans, dried distiller's grains and soluble (DDGS) and ethanol within Indiana. Three time frames were used for this study, a baseline of 2006, a short-term time frame of 2008 and a long-term scenario based in 2010.

This study focused primarily on the current and future grain-based ethanol industry in Indiana. The study used a linear programming method to minimize the transportation distances required to satisfy the corn demand by the livestock, food and ethanol industries. In addition, a linear programming model was established to minimize the transportation distance for outbound products such as DDGS and ethanol. The study assumed that inbound and outbound products could travel via truck, rail, or barge.

Quear calculated the Indiana roadway infrastructure impacts for each time frame by calculating the one-way vehicle trip miles (VTM) as well as establishing the average length of haul (LOH). He used the following formula in equation 1 to calculate the VTM.

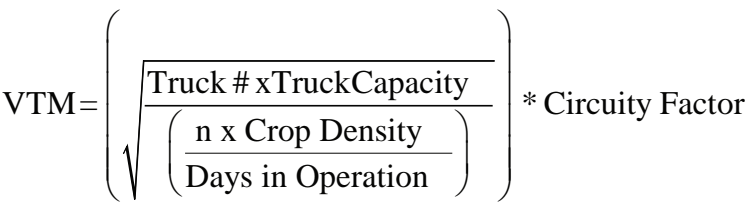

Source: Quear (2008)

In addition to the VTM calculation, Quear also estimated the average length of haul (LOH) for trucks traveling on Indiana roadways. This metric was calculated using equation 2.

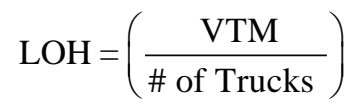

Source: Quear (2008)

The study concluded that the total VTM for all of the commodities being affected by the grainbased ethanol industry would increase for each of the time frames studied for both inbound and 
outbound VTM's. Quear (2008) estimated that the grain-based ethanol industry would increase the total VTM on Indiana roadways from 31,015,500 miles in 2006 to 45,060,400 VTM's in 2010 with the largest gain coming from corn transportation to ethanol facilities.

Another 2008 study for Iowa (Yu and Hart 2008) took a different approach. This study relied on surveys of farmers, grain handlers, livestock producers, and ethanol plants to obtain data on product flows. Products included corn, soybeans, and distillers dried grains with solubles (DDGS), a co-product of ethanol production that is used as an animal feed. The study concluded that the Iowa ethanol industry captured a considerable share of Iowa corn mainly at the expense of animal feeders and export markets. Much of the DDGS and ethanol was shipped to out-of-state markets. Transport costs were seen as a barrier to profitability and were trending upward. Transportation infrastructure generally was rated by respondents as average.

A study conducted by Trimac Consulting Services LTD (1999) for the Transport Canadian Surface Policy and Programs explored the road infrastructure impacts of grain truck traffic. The study explored how the consolidation of the grain elevator industry affected the average length of haul for trucks and the total truck miles traveled in Canada (Trimac 1999).

The study estimated the average truck haul distance to the nearest elevator by assuming that all farms are laid out in a rectangular grid and that grain production is uniform throughout the rectangle. Each of these grids were five square kilometers in size. The study used geo-coding in conjunction with grain production density maps to establish a grain density grid surrounding each of the elevator locations. Trimac (1999) mathematically determined the average length of haul, in terms of kilometers, for each truck was equal to the equation $(1 / 4 \mathrm{X}+1 / 4 \mathrm{Y})$, where $\mathrm{X}$ and $\mathrm{Y}$ are eastwest and north-south distances on the grid. The graphical illustration of this calculation is shown in Figure 1.

Figure 1: Farm to Elevator Trucking Distance on a North-South / East-West Grid

\section{Farm to E levator Distance R elationships}

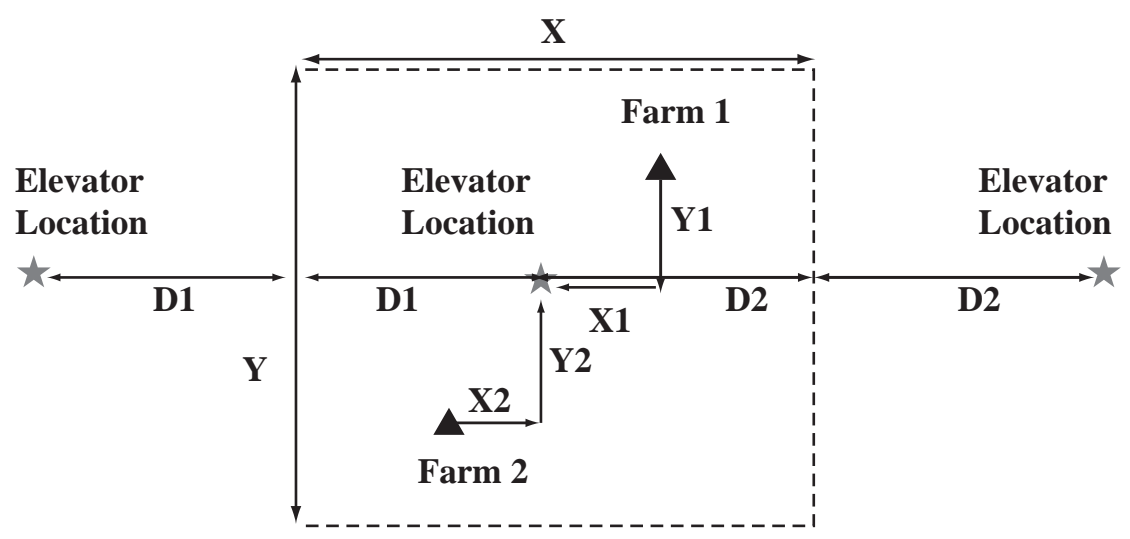

- Farm 1 is $(X 1+Y 1) \mathrm{km}$ to the elevator

- Farm 2 is (X2 +Y 2) km to the elevator

- Farms in dashed zone are nearest to same el evator

- A verage truck distance in the zone bounded by $X$ and $Y$ is $(1 / 4 X+1 / 4 Y) \mathrm{km}$

Source: Trimac (1999)

The study concluded that the equation $(1 / 4 \mathrm{X}+1 / 4 \mathrm{Y})$ could be used to calculate average length of haul for grain trucks only if the road network was a complete grid. The equation becomes flawed when diagonal routes or natural obstacles such as lakes or rivers exist. The study then created 
Figure 2: Sample Hinterlands Developed Using Arc GIS

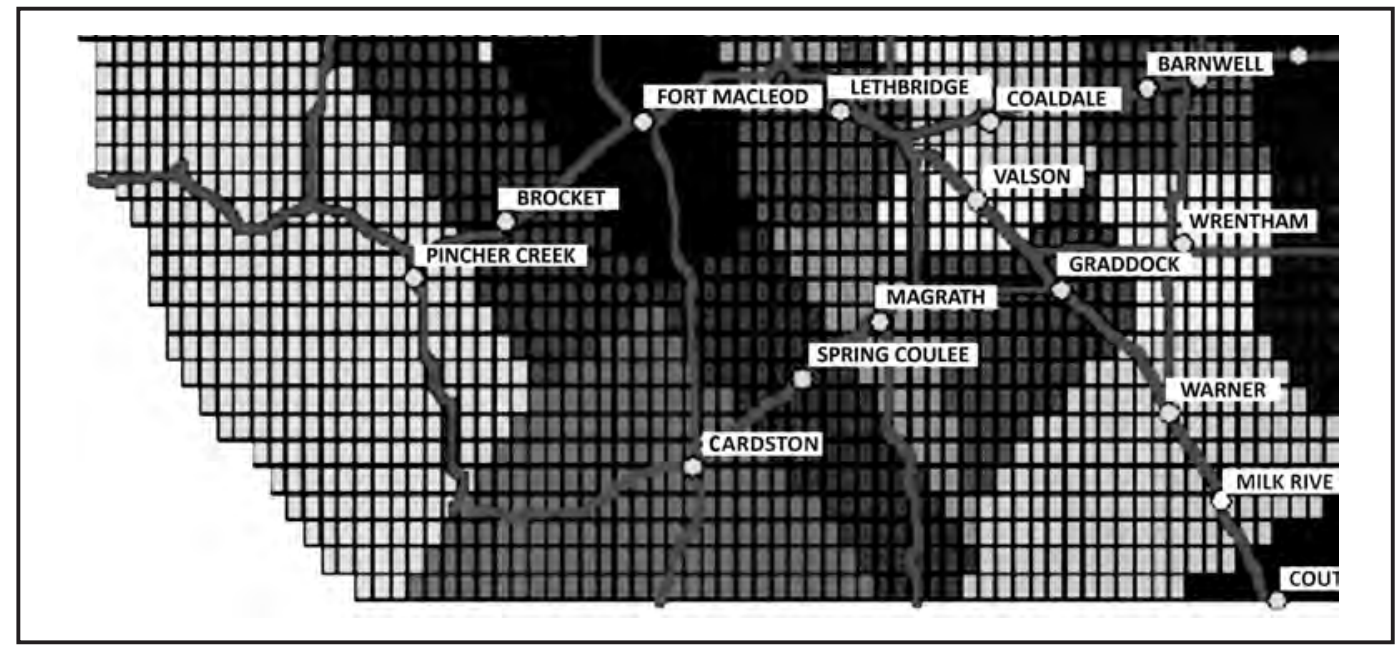

Source: Trimac (1999)

delivery "hinterlands" (delivery zones) based on the crop density grids and the above equation (Trimac 1999). This process was completed using geo-coding software. Figure 2 shows the delivery zones indicated by different shades on the map for a set of elevators in Western Canada.

The study concluded that the average length of haul was largely dependent upon the number of elevators present in a region. The study also concluded that consolidation of the elevator industry in Canada would add approximately 34 million truck-km to the road system and increase the average length of haul by $81 \%$ (Trimac Consulting Services LTD 1999).

\section{METHODS}

This section discusses the data sources, key assumptions and model development for determining the infrastructure impacts that the cellulosic biofuel industry likely will impose on the Indiana road network. Indiana county-level data is used where possible. Data regarding ideal cellulosic plant locations, biomass availability per county, road class usage, and road grids within a particular fuelshed were combined with key assumptions in an Excel model to determine the infrastructure impacts of a particular cellulosic plant. A fuelshed is defined as the area in which a particular cellulosic biofuel plant will source biomass to convert to useable biofuels.

The actual physical locations of future cellulosic biofuel plants will greatly influence the impact they have on the surrounding local infrastructure. It is assumed that cellulosic biofuel plants will be located in areas with extremely high biomass densities, thus reducing the effective radius of the fuelshed required for a particular plant to run at full capacity. A smaller fuelshed will lead to lower biomass transportation costs, thus making the plant more profitable.

The cellulosic plant locations were estimated using a cost minimization GAMS linear program model, developed by David Perkis of Purdue University (Perkis et al. 2008). Perkis estimated the top nine ideal plant locations in Indiana using a sequential cost minimization approach. That is, plant one first chooses the ideal location in Indiana, then plant two chooses the second most ideal plant location in Indiana, with the knowledge of plant one's location which influences available biomass supply. This study evaluates the infrastructure impacts of the following top three ranked cellulosic facilities. 
Cellulosic Biofuels Industry

Table 2: Cellulosic Plant Specific Locations

\begin{tabular}{ccccc}
\hline Plant & County & County Seat & Latitude & Longitude \\
\hline 1 & White & Monticello & $40^{\circ} 44^{\prime} 48^{\prime \prime} \mathrm{N}$ & $86^{\circ} 45^{\prime} 55^{\prime \prime} \mathrm{W}$ \\
2 & Tipton & Tipton & $40^{\circ} 17^{\prime} 6^{\prime \prime} \mathrm{N}$ & $86^{\circ} 2^{\prime} 25^{\prime \prime} \mathrm{W}$ \\
3 & Marshall & Plymouth & $41^{\circ} 20^{\prime} 38^{\prime \prime} \mathrm{N}$ & $86^{\circ} 18^{\prime} 45^{\prime \prime} \mathrm{W}$ \\
\hline
\end{tabular}

Source: Authors calculations done by converting the county seat to latitude and longitude using GeoHack (2008).

Using the three projected plant locations; the available biomass was estimated to determine the effective fuelshed for a particular cellulosic plant. Data for the available biomass within each of the 92 Indiana counties was obtained from (Perlack et al. 2005). The study estimated the supply of corn stover and switchgrass in terms of dry tons on a county-level basis. It was assumed that corn stover and switchgrass were being produced on separate tracts of land, thus the summation of available corn stover and switchgrass represented the total available biomass for a given county. This study assumes that all biomass will be sourced from corn stover as it is estimated to be the cheapest and most readily available material in Indiana (Brechbill et al. 2008). The Perlack et al. (2005) data was then altered to represent more localized estimations of the Indiana sustainable removal rates, farmer participation, and storage losses. Table 3 shows the assumptions for each scenario. Scenario one represents the current 'best case' case scenario while scenario two represents the 'worst case' scenario in terms of sustainable removal rate and farmer participation. Scenario three only differs from scenario one in the higher biofuel yield of 89.1 gallons of biofuel per ton of corn stover. Scenario three represents a biofuel yield that may be associated with future cellulosic plants (Bain 2007), and thus could represent possible future infrastructure impacts. Plant size is held at 50 million gallons in all three scenarios.

Table 3: Biomass Supply Scenarios

\begin{tabular}{lccc}
\hline & Scenario 1 & Scenario 2 & Scenario 3 \\
\hline Sustainable Removal Rate (\%) & $52.5 \%$ & $38 \%$ & $52.5 \%$ \\
Farmer Participation (\%) & $75.0 \%$ & $50 \%$ & $75 \%$ \\
Storage Loss (\%) & $8.4 \%$ & $8.4 \%$ & $8.4 \%$ \\
Biofuel Yield from Corn Stover (gal/ton) & 69.7 & 69.7 & 89.1 \\
\hline
\end{tabular}

The original Perlack et al. (2005) biomass data was altered with each of the scenario assumptions to determine the biofuel density as established by equation 3 :

(3) Biofuel Density $=\left[\frac{\mathrm{T} \times \mathrm{S} \times \mathrm{F} \times(1-\mathrm{L})}{\mathrm{M}}\right] \times$ Yield

where T is the Perlack et al. (2005) estimated total dry tons of biomass per county, $\mathrm{S}$ is the sustainable removal rate, $\mathrm{F}$ is the farmer participation level, $\mathrm{L}$ is the storage loss, $\mathrm{M}$ is the square miles in a given county and Yield is the gallons of biofuel produced per dry ton of biomass. The biofuel density simply represents the number of gallons of biofuel that can be produced per square mile of land (U.S. Census Bureau 2009).

GIS ArcMap version 9.2 was used to determine the physical fuelsheds surrounding the top three most ideal plant locations in Indiana. To establish the projected fuelshed for a particular plant, the area in square miles that exists within specified distances of a plant was calculated on a county level basis. Using a methodology similar to the Brechbill et al. (2008) study, concentric circles 
were drawn around each plant in five mile increments The area within each county between the concentric circles was then calculated by using the intersect tool. The intersect tool simply uses county lines and the concentric circles to establish the amount of area that can be attributed to each of the counties within a particular concentric circle. For example, within the five mile concentric circle of the White County plant location, two counties exist, White and Carroll County. In total there are 78.6 square miles of land within this five mile circle as established by using $\mathrm{A}=\pi \mathrm{r}^{2}$. Using the intersect tool it was shown that 20.5 square miles lie within Carroll County and 58.1 square miles lie within White County as shown in Table 4.

Table 4: Area within Counties for Given Buffer Zones

\begin{tabular}{cc}
\hline County & 0 to 5 miles \\
\hline Carroll & 20.5 \\
White & 58.1 \\
Total & 78.6 \\
\hline
\end{tabular}

Source: Author's Calculations (2009)

Calculating the physical area within each county for areas that have overlapping fuelsheds follows the methodology stated above but uses the intersect tool one more time to establish area for the first plant that was built.

Combining the county area data established by the ARC GIS software and the biofuel density data, the required fuelshed for each of the top three cellulosic plants is established using equation 4:

(4) 0 Million gal $=\left[\left(\left(D^{5} x\left(C^{5}-C^{0}\right)\right)+\left(\left(D^{10} x\left(C^{10}-C^{5}\right)\right) \ldots\left(\left(D^{x} \times\left(C^{x}-C^{x-5}\right)\right)\right]\right.\right.\right.$

where $\mathrm{D}^{\mathrm{x}}$ is the weighted average biofuel density for the counties that lie within that specific buffer zone, and $\mathrm{C}$ are square miles of biomass available within the specific buffer zone. A buffer zone is simply the area between two concentric circles. For example, the $\mathrm{C}^{10}$ concentric circle represents the area within 10 miles of a specific plant, which equates to approximately 314 square miles. Using the same $\mathrm{A}=\pi \mathrm{r}^{2}$ equation, the $\mathrm{C}^{5}$ concentric circle has 78.6 square miles. Thus the above equation establishes the area in between the five and 10 mile circles as 235.4 square miles as determined by $\mathrm{C}^{10}-\mathrm{C}^{5}$ which is also defined as the $\mathrm{C}^{10}$ buffer zone. Likewise, the average density of biofuel that can produced per square mile in the area between the five and 10 mile circles is denoted as $\mathrm{D}^{10}$ The number of square miles available is then multiplied by the weighted average biomass density to determine the number of biofuel gallons produced within the given buffer zone. In simple terms, this equation simply adds the number of gallons supplied to the plant by each county within a given concentric circle of the plant to the point where the cellulosic plant demand is satisfied. Thus to determine when the summation of the number of gallons of biofuel supplied by each county within a given distance of the plant equals the required 50 million gallons, the equation must be solved for $\mathrm{X}$ (equation 5).

$$
X=\frac{\left\{50 \text { Million gal- }\left[\left(\left(D^{5} \times\left(C^{5}-C^{0}\right)\right)\right)+\left(\left(D^{10} \times\left(C^{10}-C^{5}\right)\right)\right]\right\}\right.}{D^{x}}
$$

Solving for $\mathrm{X}$ establishes the distance (radius) an individual cellulosic plant will have to go to source the required biomass in order to run at capacity. It is assumed that this distance is uniform surrounding an individual plant with the exception of areas where overlapping fuelsheds exists. 
Cellulosic Biofuels Industry

Figures 3, 4, and 5 represent the projected fuelsheds under each of the scenarios.

Figure 3: Scenario 1 Plant Locations

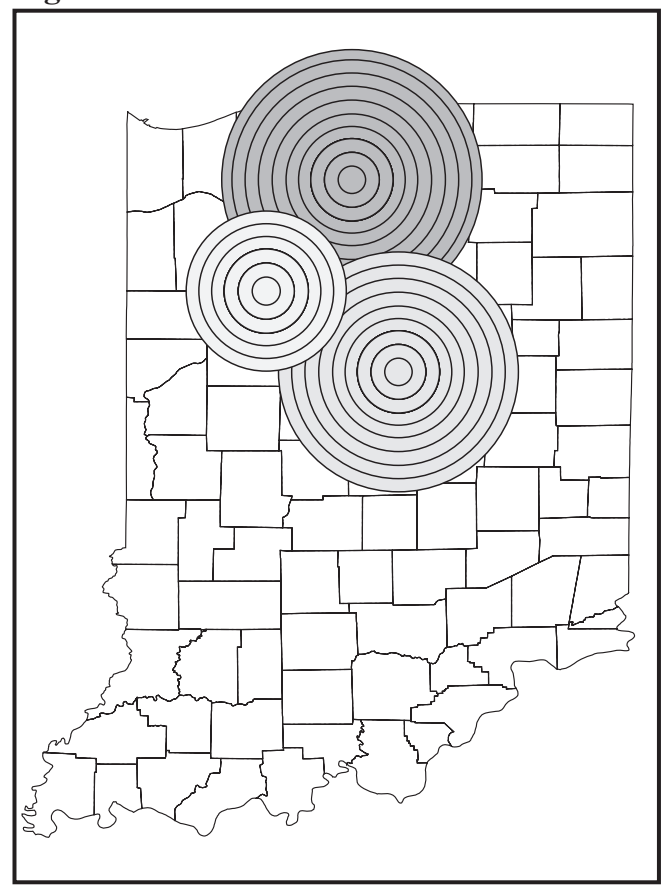

Figure 4: Scenario 2 Plant Locations

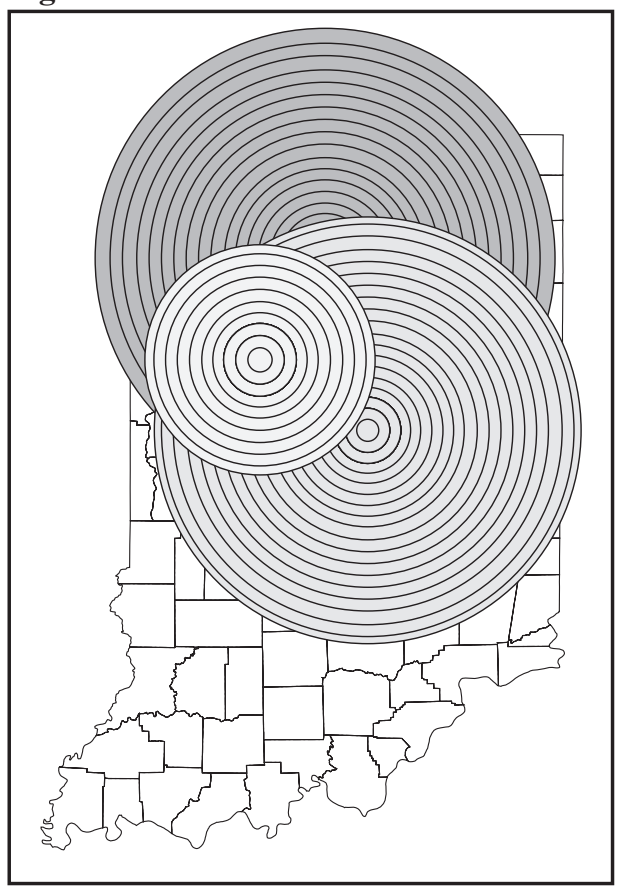

Figure 5: Advanced Biofuel Yield Fuelshed

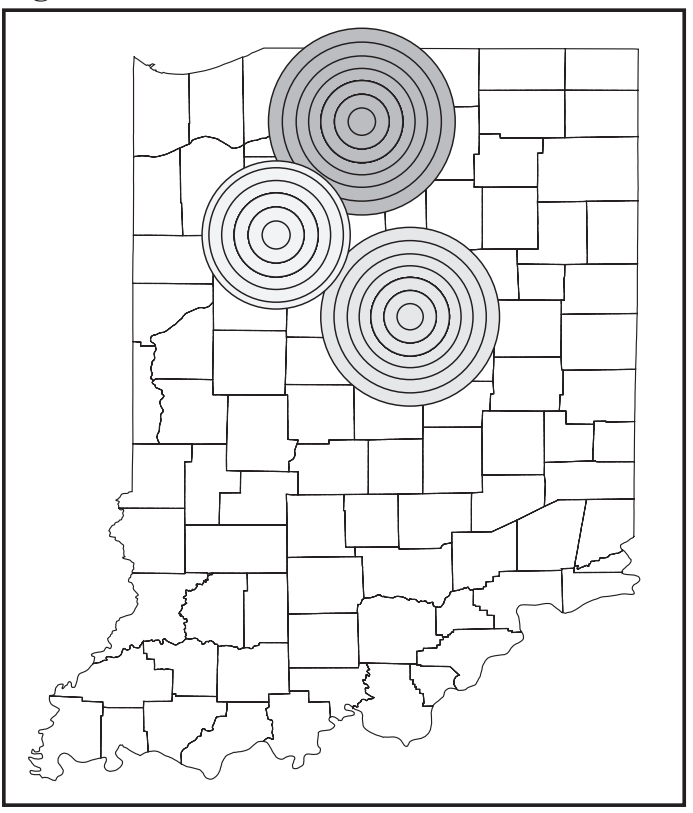

With the fuelsheds established, the infrastructure impacts were calculated using the following methodology. 


\section{Truckloads}

This study assumes that all trucks transporting biomass to one of the three analyzed cellulosic facilities will each carry 26 round bales of biomass. Brechbill et al. (2008) suggest that 26 bales each weighing .5 tons, thus 13 total tons, would be the maximum capacity that each truck can safely transport. Tons transported for the cellulosic platforms are based on 14-ton empty tractor/trailer and 13-ton load capacity (Brechbill et al. 2008). Tons transported for the grain based platform analyzed subsequently are based on 14-ton empty tractor/trailer, $920 \mathrm{bu}$ grain capacity (weighing $56 \mathrm{lbs} / \mathrm{bu}$ ) and 25-ton capacity of Dried Distillers Grains with Solubles (DDGS) (Quear 2008). DDGS is a co-product of corn ethanol production.

To determine the number of trucks needed to supply the biomass for a given plant the following equation is used:

(6) Truckloads $=\left(\frac{\text { Plant Capacity }}{\text { Biomass Y ield } x \text { Truck Capacity }}\right)$

Each plant would need approximately 55,182 semi truck deliveries per year to provide an adequate supply of biomass to run at the 50 million gallon plant capacity.

\section{One-way Annual Truck Miles and Average Length of Haul}

An important measure of road infrastructure impact is the number of loaded miles that are being traveled on a specific set of roads. One-way annual truck miles (VTM) are the total number of miles driven by the trucks delivering biomass to the cellulosic facilities. VTM's are determined based on the location of the biomass relative to the location of the cellulosic plant, thus the distance the trucks need to travel to deliver biomass. To determine the VTM, the number of truck loads within each buffer zone is calculated. The 55,182 trucks that are needed to supply biomass to each cellulosic plant are allocated into their buffer of origin. For example Table 5 shows the number of available tons that are contracted to go to Plant 1 within 0 to five miles of the plant. To transport the 23,504 tons of available biomass within the five miles of the plant, 1,808 truck trips are needed. Thus, 1,808 trucks originate their trip within the five mile buffer zone.

Table 5: Buffer Zone Located Between 0 and 5 Mile Concentric Circles

\begin{tabular}{lccc}
\hline County & $\begin{array}{r}\text { Available Biomass } \\
\text { (tons) }\end{array}$ & $\begin{array}{r}\text { Truckloads Needed } \\
\text { (\# of trucks) }\end{array}$ & $\begin{array}{r}\text { VTM } \\
\text { (miles) }\end{array}$ \\
\hline Carroll & 5,460 & 420 & 1,779 \\
White & 18,044 & 1,388 & 5,880 \\
Total & 23,504 & 1,808 & 7,659 \\
\hline
\end{tabular}

Source: Author's Calculations (2009)

The VTM is then calculated by using equation 7 :

(7) VTM=Circuity factor $\mathrm{x}$

$$
\left[\left(\mathrm{T}^{5} \mathrm{x} \sqrt{\left(\frac{\left(\left(\frac{\left(\mathrm{A}_{5}-\mathrm{A}_{0}\right)}{2}\right)+\mathrm{A}_{0}\right)}{\pi}\right)}\right)+\ldots\left(\mathrm{T}^{\mathrm{x}} \mathrm{x} \sqrt{\left.\left(\frac{\left(\left(\frac{\left(\mathrm{A}_{\mathrm{x}}-\mathrm{A}_{\mathrm{x} 5}\right)}{2}\right)+\mathrm{A}_{\mathrm{x} 5}\right)}{\pi}\right)\right)}\right)\right]
$$


where $\mathrm{T}$ is the number of trucks that originate within the corresponding buffer zone, $\mathrm{A}$ is the area within the concentric circle and the circuitry factor is the correction for non-direct road routes. The circuitry factor in this analysis is 1.2 which means that $20 \%$ of the VTM are for trucks traveling on roads that do not lead directly to the cellulosic plant (Quear 2008).

For example, $\mathrm{T}^{5}$ represents the number of trucks that originate within the five mile buffer zone, or simply the number of trucks that originate between 0 and five miles of the plant location. To determine the area, this analysis assumes that the biomass is evenly distributed within a specific buffer zone. The average truck will travel the distance above the lower bound and below the upper bound required to service half of the square miles within a buffer distance. Referring to Table 5, the five mile buffer represents the distance 0 to 5 miles from Plant 1 . Given the formulae for the area of a circle, $\mathrm{A}=\pi \mathrm{r}^{2}$, the halfway point for biomass is not 2.5 , but is derived from the circle formulae. For the first circle (0-5 miles), the area is $78.54 \mathrm{sq}$. mi, thus 39.27 is half of the square miles within this buffer zone. The halfway point is the square root of $39.27 / \pi$. Thus, the average distance of biomass origination is 3.53 miles for the first zone. Multiplying the 1,808 trucks $\left(\mathrm{T}^{5}\right)$ that are needed to transport the biomass by the average distance of 3.53 miles and the circuitry factor of 1.2 , the total VTM for this buffer zone is 7,659 miles. This process is repeated for each of the buffer zones surrounding a particular cellulosic plant, and the summation of the VTM's within each buffer zone represents the total road infrastructure impact for that plant.

The average number of miles for each truck delivering biomass to a cellulosic plant is referred to as the average length of haul $(\mathrm{LOH})$. $\mathrm{LOH}$ is determined based on the following equation:

$$
\mathrm{LOH}=\frac{\mathrm{VTM}}{\text { Truckloads }}
$$

Source: (Quear 2008)

where VTM is the total VTM for a given plant and truckloads are the total truckloads delivered to a plant per year.

\section{Road Class Usage}

To obtain a better idea of the type of roads that will be used for biomass delivery, this section outlines the methodology and data used to calculate the VTM based on functional road class (FC). Indiana roadways are classified based on whether the section of roadway is located in rural or urban areas, if it is a federal interstate, and the overall level of traffic that occurs. The Indiana Department of Transportation (INDOT) ranks Indiana roads on a scale of 1 to 19 (Indiana Department of Transportation 2007). Road classes 1 through 9 are rural roads while road classes 11 through 19 are urban roads.

Using data from the Federal Highway Administration's (FHA) vehicle travel information system (VTRIS), this study estimated the FC of roads that will receive the most travel within each of the fuelsheds (Federal Highway Administration 2009). The VTRIS is a vehicle monitoring program that attempts to estimate traffic for various types of vehicles on various types of roadways throughout the country. VTRIS reports both current and historical average daily counts of five axle semi trucks for each of the Indiana road classes. This study used average daily data for 2008.

To compare the average truck counts across road classes, the total miles of roadway for each road class in Indiana was determined using Arc GIS. The average daily trucks per mile is the average daily number of observed trucks that travel on each mile of a particular road class in Indiana.

Arc GIS was used to determine the actual road classes and the number of total road miles that exist within each of the buffer zones. The roads, road classes and number of miles were determined for each buffer zone surrounding the cellulosic plants by using the ArcGIS intersect tool and a road infrastructure overlay (Indiana Department of Transportation 2004). The proportion of roadway use by FC within each of the buffer zones and the average daily truck per mile data was combined with 
the roadway miles by FC within each of the fuelsheds to determine a weighted average by using equation 9:

(9) $100=\mathrm{A}\left[\left(\mathrm{T}_{1} \times \mathrm{M}_{1}\right)+\ldots\left(\mathrm{T}_{2} \times \mathrm{M}_{2}\right)\right]$

where $\mathrm{A}$ is an adjustment factor that is used to adjust the actual miles of a $\mathrm{FC}$ within a buffer zone compared to the total miles of a FC within the state, $\mathrm{T}$ is the trucks per mile for each $\mathrm{FC}$, and $\mathrm{M}$ is the miles of $\mathrm{FC}$ within a particular buffer zone. The equation is then solved for A using equation 10:

$$
A=\frac{100}{\left[\left(T_{1} \times M_{1}\right)+\ldots\left(T_{2} \times M_{2}\right]\right.}
$$

The adjustment factor is then multiplied by the $\mathrm{T}$ and $\mathrm{M}$ for each $\mathrm{FC}$ class to determine the percent of the VTM within the particular buffer zone that are projected to be traveled on that FC. For example, Table 6 shows data from the 10-mile buffer zone for Plant 1 . The table indicates that only three types of road classes fall within this specific buffer zone, FC 2, FC 3 and FC 7. The average daily trucks per mile represent the Federal Highway Adminstration (2009) truck observation data divided by the total miles of FC within the state. Note that the truck per mile ratio remains constant regardless of plant location or buffer distance as this is a statewide calculation. The miles of FC in the buffer zone are the actual number of roadway miles present in that particular buffer zone surrounding the plant. In this example, there are 24.2 miles of FC 2, 6.8 miles of FC6 and 85.4 miles of FC7 roadways within the 10-mile buffer zone. The numbers are then adjusted using the adjustment factor as calculated in the equation (7). By multiplying the adjustment factor by $\mathrm{T}$ and $\mathrm{M}$, the weighted percentage by FC is established. For example, the weighted FC for road class 2 is calculated by multiplying T (.25), M (24.2) and A (14.7) to establish a weighted average of $89 \%$.

Table 6: Functional Road Class Percentage for 10 Mile Buffer Zone

\begin{tabular}{ccccc}
\hline Road Class & $\begin{array}{c}\text { Daily Trucks per } \\
\text { Mile (T) } \\
(\text { trucks/mile) }\end{array}$ & $\begin{array}{c}\text { Miles of FC } \\
(\mathrm{M})\end{array}$ & $\begin{array}{c}\text { Adjustment } \\
\text { Factor } \\
(\mathrm{miles})\end{array}$ & $\begin{array}{c}\text { Weighted FC } \\
\text { (Portion of VTM by FC) }\end{array}$ \\
\hline 2 & .25 & 24.2 & 14.7 & $\%$ \\
3 & .05 & 6.8 & 14.7 & $89 \%$ \\
7 & .0047 & 85.4 & 14.7 & $5 \%$ \\
Total & & 116.4 & & $100 \%$ \\
\hline
\end{tabular}

Source: Author's Calculations (2009)

The total VTM per functional road class for each plant is calculated by multiplying the number of miles that travel through each buffer zone, the weighted functional class percentage, and the circuitry factor of 1.2. The trucks that collect biomass within a buffer zone have to travel through other buffer zones to reach the cellulosic plant (except if starting 0 to five miles from plant). As the trucks travel from zone to zone, the available road types change, thus forcing trucks to switch roads. The actual VTM's traveled within each buffer zone are a combination of VTM's from trucks originating in that buffer zone and from the trucks that had to pass through the buffer in route to the cellulosic plant. 


\section{RESULTS}

This section estimates the impacts of cellulosic biomass transportation on road infrastructure for all scenarios.

The size of the fuelshed and the location of the biomass within the fuelshed directly translate into the impact that an individual cellulosic plant will have on the road infrastructure. Table 7 shows the impacts of the three most ideal plant locations in Indiana for all of the scenarios. To estimate road impacts, one-way loaded vehicle trip miles (VTM), the number of truckloads required to deliver the biomass, and the average length of haul $(\mathrm{LOH})$ for each plant were calculated under each scenario.

White County (plant 1) is projected to have the least VTM of the counties in scenario 1, although it is still significant compared to the infrastructure impacts of grain-based ethanol plants. The total VTMs traveled for plant 1 are about 1.3 million miles in scenario 1 . It will take approximately 55,194 truck trips to deliver the necessary biomass for plant 1, thus establishing an LOH of 24.1 miles. The length of haul simply means that the average truck delivering biomass to the White County cellulosic plant will need to travel 24.1 miles from biomass origination to the physical plant location.

As more plants are built, the infrastructure impacts increase. The trucks delivering biomass to the Tipton County plant under scenario one will travel about 1.7 million miles. This is approximately $27 \%$ more VTM than the impact of the White County plant. As the VTM increases, so does the average LOH which is estimated to be 30.6 miles for the Tipton County plant under scenario one.

The third constructed cellulosic plant (Marshall County) is projected to have a total road impact of about 1.9 million VTM. This is a $40.9 \%$ increase in road impact compared to the White County Plant. The LOH also increased from plant's 1 and 2 because it cannot source biomass that is contracted to go to the previously built cellulosic plants, thus increasing the distance required to source biomass to 33.7 miles.

Table 7 also shows the total road impacts for scenario 2. The estimated VTM for the White County plant is about two million, with the average length of haul increasing to 36.2 miles. The infrastructure impacts increase greatly for the subsequent plants under scenario 2. The Tipton County plant is estimated to cause about 3.7 million additional VTM to the road network, an $88 \%$ increase over plant 1 in the second scenario. The Marshall County plant is projected to require 4.7 million VTM in order to deliver the biomass, and a LOH of 85.5 miles. The roads impacts for the Marshall County plant are $137 \%$ greater than the impacts of the White County plant under the same scenario.

The average impact in terms of VTM on Indiana's roadways for scenario 1 is about 1.6 million miles per cellulosic plant, while the average VTM for scenario 2 is about 3.5 million road miles per plant. Thus, a $51.7 \%$ decrease in the available biomass supply (scenario 1 farmer participation and removal rates vs. scenario 2), is projected to increase the VTM by $114 \%$. The reason for the large increase in VTM's relative to the reduction in biomass is because of the competition effect of plants wanting to locate in the biomass rich areas of Indiana.

If the scenario of three estimations for biofuel yield become reality and cellulosic plants are able to collect biomass at the farmer participation and removal rates established in scenario 1, the total road impacts for a cellulosic industry in Indiana would be much less. Table 8 shows that average cellulosic plant would contribute approximately one million VTM assuming the scenario three estimates, which is $37 \%$ less than the average VTM traveled under scenario 1 , and $71 \%$ fewer VTM compared to scenario 2. 
Table 7: Infrastructure Impacts: VTM, Truckloads and LOH

\begin{tabular}{|c|c|c|c|c|}
\hline & County & $\begin{array}{l}\text { VTM } \\
\text { (miles) }\end{array}$ & $\begin{array}{l}\text { Truckloads } \\
\text { (\# trucks) }\end{array}$ & $\begin{array}{l}\mathrm{LOH} \\
\text { (miles) }\end{array}$ \\
\hline \multirow{4}{*}{ Scenario 1} & $\begin{array}{l}\text { White County } \\
\text { (Plant 1) }\end{array}$ & $1,327,961$ & 55,194 & 24 \\
\hline & $\begin{array}{l}\text { Tipton County } \\
\text { (Plant 2) }\end{array}$ & $1,686,617$ & 55,084 & 31 \\
\hline & $\begin{array}{l}\text { Marshall County } \\
\text { (Plant 3) }\end{array}$ & $1,871,709$ & 55,585 & 34 \\
\hline & Average & $1,628,762$ & 55,288 & 29 \\
\hline \multirow{4}{*}{ Scenario 2} & $\begin{array}{l}\text { White County } \\
\text { (Plant 1) }\end{array}$ & $1,988,892$ & 54,889 & 36 \\
\hline & $\begin{array}{l}\text { Tipton County } \\
\text { (Plant 2) }\end{array}$ & $3,748,019$ & 55,037 & 68 \\
\hline & $\begin{array}{l}\text { Marshall County } \\
\text { (Plant } 3)\end{array}$ & $4,707,629$ & 55,087 & 85 \\
\hline & Average & $3,481,513$ & 55,004 & 63 \\
\hline \multirow{4}{*}{ Scenario 3} & $\begin{array}{l}\text { White County } \\
\text { (Plant 1) }\end{array}$ & 898,791 & 42,899 & 21 \\
\hline & $\begin{array}{l}\text { Tipton County } \\
\text { (Plant 2) }\end{array}$ & $1,024,560$ & 42,122 & 24 \\
\hline & $\begin{array}{l}\text { Marshall County } \\
\text { (Plant 3) }\end{array}$ & $1,136,494$ & 42,613 & 27 \\
\hline & Average & $1,019,948$ & 42,545 & 24 \\
\hline
\end{tabular}

\section{Cellulose Biofuels Compared With Grain Ethanol}

The road impacts of the cellulosic ethanol industry are substantial when compared to the road infrastructure impacts of the grain-based ethanol industry. Table 8 shows the total VTMs for each of the scenarios in this study in addition to the total direct VTM impact of the grain-based ethanol industry in Indiana. For consistency, the grain-based VTM's only include direct incoming corn and outgoing DDGS, thus simply the direct impact of the grain-based ethanol industry (Quear 2008). The total VTMs were divided by the total gallons of biofuel produced, thus allowing comparison between the smaller cellulosic facilities and the larger grain-based ethanol facilities. Table 8 indicates that the VTM per gallon of biofuel produced is $218 \%$ higher in scenario one and $583 \%$ higher in scenario two when compared to the Indiana grain based ethanol industry (Quear 2008). Scenario three is projected to have a $101 \%$ greater VTM impact per gallon of capacity when compared to the grain based ethanol industry. It should be noted that scenario one is considered the 'best case' scenario for first generation cellulosic plants in this case study. Thus this study suggests that the infrastructure impact on a per gallon basis of cellulosic biofuel produced is sustainably higher than a gallon of grain-based ethanol produced. 
Table 8: Cellulosic VTM Impacts Compared to Grain Ethanol

\begin{tabular}{lcccc}
\hline & $\begin{array}{c}\text { Total VTM } \\
(\mathrm{vtm})\end{array}$ & $\begin{array}{c}\text { Total Gallons Produced } \\
(\mathrm{gal})\end{array}$ & $\begin{array}{c}\text { VTM per Gallon } \\
(\mathrm{vtm} / \mathrm{gal})\end{array}$ & $\begin{array}{c}\text { \% Change Relative } \\
\text { to Grain-Based }\end{array}$ \\
\hline Scenario 1 & $4,886,287$ & $150,288,419$ & 0.0325 & $218 \%$ \\
Scenario 2 & $10,444,539$ & $149,518,340$ & 0.0699 & $583 \%$ \\
Scenario 3 & $3,059,845$ & $148,833,828$ & 0.0206 & $101 \%$ \\
Grain Based Ethanol * & $4,656,100$ & $455,000,000$ & 0.0102 & \\
\hline
\end{tabular}

*Based on Quear 2008 study. Only includes direct inbound corn and outbound DDGS impacts for 2008 scenario.

Trucks carrying biomass to cellulosic facilities will weigh significantly less than trucks transporting inbound grain and outbound DDGS from grain based ethanol facilities. In order to consider the weight differential, ton-miles per gallon of capacity were calculated for each scenario in Table 9. Ton-miles are simply the number of tons transported (trucks * load weight) multiplied by the number of miles traveled (VTM). The total ton-miles were then divided by the total gallons produced for each scenario to determine the ton-miles per gallon of capacity. Table 9 indicates that under scenario one, the cellulosic ethanol industry will have a $65 \%$ greater impact on the road infrastructure compared to the grain ethanol industry on a ton-mile per gallon basis. The impact would be $255 \%$ more severe than the grain based industry under scenario two. If the scenario three estimates are accurate, then the cellulosic industry would have a very similar impact on the road infrastructure on a ton-mile per gallon of capacity basis when compared to the grain industry.

Table 9: Ton-Miles per Gallon of Biofuel Capacity

\begin{tabular}{lcccc}
\hline & $\begin{array}{c}\text { Million-Ton-Miles } \\
\text { (ton-miles) }\end{array}$ & $\begin{array}{c}\text { Total Gallons } \\
\text { Produced } \\
\text { (saleable gal.) }\end{array}$ & $\begin{array}{c}\text { Ton-Miles per } \\
\text { Gallon } \\
\text { (ton-mile/gal) }\end{array}$ & $\begin{array}{c}\text { \% Change Relative } \\
\text { to Grain-Based }\end{array}$ \\
\hline Scenario 1 & $63,521,731$ & $150,288,419$ & 0.4227 & $65 \%$ \\
Scenario 2 & $135,779,020$ & $149,518,340$ & 0.9081 & $255 \%$ \\
Scenario 3 & $39,777,985$ & $148,833,828$ & 0.2673 & $4 \%$ \\
Grain Based Ethanol & $116,402,500$ & $455,000,000$ & 0.2558 & \\
\hline
\end{tabular}

Source: Author's Calculations (2009)

\section{Cellulose Ethanol Compared to Total Truck Traffic}

Given the central collection points of the proposed cellulosic plants, the highest concentration of infrastructure impacts will occur in the immediate vicinity of the plants. To determine the local impact of cellulosic plants, the study compared the ton-miles of biomass movement to the overall ton-miles of all commercial vehicles within a 20-mile radius of each of the plants. As a starting point, annual state-wide ton-mile data, less through ton-miles, were used as the benchmark for local commercial truck infrastructure impacts (Federal Highway Administration 2009). A 20-mile radius was selected as fuelshed overlap is minimal at this distance and also most impacts would be closer to the plant. The total ton-miles for Indiana in 2002 were estimated to be 30.8 billion. The state ton-mile data was then converted to county level, ton-mile per square mile data, by using the relative daily truck counts for the three counties with plant locations. For example, 95,608 commercial vehicles were observed per day in White County, which is $1.1 \%$ of the total 8.6 million commercial vehicles observed Indiana-wide for 2007 (Indiana Department of Transportation. 2007). The 1.1\% was then multiplied by 30.8 billion statewide ton-miles to establish an estimate of 343.6 million ton-miles for White County. The ton-miles per county was then divided by the square miles to 
determine the estimated ton-miles per square mile. This step was repeated for each of the three counties with plant locations to establish a commercial ton-mile per square mile estimate.

The average commercial ton-miles for each county was then multiplied by 1256 square miles, which is simply the square miles that exists within a five mile radius of each plant. This determined an estimated 361.6 to 1031.5 million ton-miles within 20 miles of each of the 50 million gallon per year plants as shown in Table 10. The large range of ton-mile estimates for each of the counties is the result of a vast difference in observed truck volumes for the counties. The cellulosic ton-miles were then determined by multiplying the number of VTMs that occur within 0 to 20 miles of each plant by 13 tons per truck. Scenario 1 and 2 are assumed to be the same as the ton-miles would be relatively equal within 20 miles of the plants because the main difference is size (total area) needed for the fuelshed with little difference in the first 20 mile radius. Scenario 3 differs as fewer trucks will be needed to move biomass because of the higher biomass yield. Table 10 suggests that a 50 MGPY cellulosic plant under scenario 1 or 2 would increase the burden on local infrastructure by $1.2 \%$ for Marshall County, $1.7 \%$ for White County and $4.2 \%$ for Tipton County. Under scenario 3, the ton-miles are projected to increase by $0.9 \%$ for Marshall County, $1.4 \%$ for White County and $3.2 \%$ for Tipton County.

Table 10: 20-Mile Radius Local Infrastructure Impact

\begin{tabular}{c|l|c|c|c}
\hline & & $\begin{array}{c}\text { Cellulosic } \\
\text { Ton-Miles }\end{array}$ & $\begin{array}{c}\text { Total } \\
\text { Ton-Miles }\end{array}$ & \% Change \\
\hline Scenario 1 \& 2 & Plant 1: White & $14,611,099$ & $847,988,943$ & $1.7 \%$ \\
& Plant 2: Tipton & $15,059,890$ & $361,632,212$ & $4.2 \%$ \\
& Plant 3: Marshall & $12,496,173$ & $1,031,502,718$ & $1.2 \%$ \\
\hline Scenario 3 & Plant 1: White & $11,454,049$ & $847,988,943$ & $1.4 \%$ \\
& Plant 2: Tipton & $11,695,880$ & $361,632,212$ & $3.2 \%$ \\
& Plant 3: Marshall & $9,188,193$ & $1,031,502,718$ & $0.9 \%$ \\
\hline
\end{tabular}

Source: Authors' calculations (2009)

\section{Vehicle Trip Miles (VTM) by Functional Road Class}

To gain a better picture of the infrastructure impacts, the total VTM's established above were then classified by function road class (FC). The number of VTM per FC was estimated using the weighed FC percentage. The sum of all road buffers within the fuelshed give the total VTM's per FC for each of the cellulosic plants. The total VTM's by FC are exactly equal to the total VTM's for the cellulosic plant.

The average VTM's per FC for a cellulosic plant in Indiana are shown in Table 11. In scenario 1, the largest portion of roadway travel, $46 \%$, is projected to take place on FC 02, other principle arterial roads. Principle arterial roads are high-capacity roads such as state routes or major county roads that flow traffic towards interstate highways. Both rural (FC 01) and urban (FC 11) interstates are each projected to have $12 \%$ of the truck miles delivering biomass to the cellulosic plants in scenario 1.

In scenario 2, rural interstates (FC 1) such as I-65 should experience 30\% of the predicted VTM volume while urban interstates (FC 11) are predicted to have $24 \%$ of the VTM impact this road class. The increase in travel on FC 1 and FC 11 interstates is due to the increasing size of the fuelsheds for the cellulosic plants. As the fuelsheds increase, they intersect more miles of interstate highway, which are the preferable roads for truck travel. FC 2 is projected to have 807,260 miles of road travel for each cellulosic plant built under scenario 2, which is $23 \%$ of the average VTM's per plant. 
Table 11: VTM by Functional Class

\begin{tabular}{r|cc|cc|cc}
\hline & \multicolumn{2}{|c|}{ Scenario 1 } & \multicolumn{2}{c|}{ Scenario 2 } & \multicolumn{2}{c}{ Scenario 3 } \\
\hline (FC) & VTM & $\%$ of Total & VTM & $\%$ of Total & VTM & $\%$ of Total \\
\hline 1 & 197,134 & $12 \%$ & $1,057,280$ & $30 \%$ & 80,040 & $8 \%$ \\
2 & 745,022 & $46 \%$ & 807,260 & $23 \%$ & 547,840 & $54 \%$ \\
6 & 65,004 & $4 \%$ & 89,335 & $3 \%$ & 45,625 & $4 \%$ \\
7 & 50,726 & $3 \%$ & 61,216 & $2 \%$ & 36,995 & $4 \%$ \\
11 & 191,727 & $12 \%$ & 827,677 & $24 \%$ & 62,285 & $6 \%$ \\
12 & 220,619 & $14 \%$ & 386,993 & $11 \%$ & 142,743 & $14 \%$ \\
14 & 115,386 & $7 \%$ & 187,742 & $5 \%$ & 76,501 & $8 \%$ \\
16 & 43,145 & $3 \%$ & 60,985 & $2 \%$ & 27,920 & $3 \%$ \\
17 & 0 & $0 \%$ & 3,026 & $0 \%$ & 0 & $0 \%$ \\
\hline Total & $1,628,762$ & $100 \%$ & $3,481,513$ & $100 \%$ & $1,019,948$ & $100 \%$ \\
\hline Sour
\end{tabular}

Source: Author's Calculations (2009)

Assuming the scenario three biofuel conversion rate, 54\% of truck traffic will occur on FC 2 roadways with only $8 \%$ of miles being traveled on rural interstates. Thus, this case suggests that the largest portion of infrastructure impacts stemming from cellulosic plants will take place on larger roads such as FC 1 and FC 2 roadways.

\section{CONCLUSIONS}

For a cellulosic biofuel industry to develop in states like Indiana, producers must believe that the plants will be profitable and that biomass collection is feasible. In addition, policy makers must be aware of all of the impacts of a future cellulosic biofuel industry, including the impact that biomass transportation will have on the road infrastructure.

An advantage that the cellulosic industry has compared to the grain-based ethanol industry is that the development of cellulosic biofuel plants is likely to be much slower, allowing producers to be more strategic with regard to plant location. By minimizing the transportation distance required to source biomass, the cellulosic biofuel plants will improve plant profitability through lower marginal transportation costs and concurrently reduce the impact on road infrastructure.

The formation of a cellulosic biofuel industry in Indiana will have major impacts on the road infrastructure surrounding each plant. The study finds that the average 50 million gallon per year cellulosic plant will need to have 55,182 truckloads of biomass delivered to the plant per year. This assumes that the biomass to biofuel conversion rate is 69.7 gallons per ton as in scenarios one and two. For this to be feasible, a truck will enter the cellulosic facility every 10 minutes, 24 hours a day, 365 days a year. If the biomass to biofuel yield of 89.7 gallons per ton occurs as in scenario three, then the average truckloads per 50 million gallon per year plant would decrease to 42,878 . This would result in a truck being unloaded every 12 minutes.

The best indicator of road infrastructure impact is the VTM for each of the cellulosic plants. The case study finds that the VTM's are the smallest for the first plant built under all scenarios. Subsequent plants are forced to locate in areas of less biomass density, thus the LOH and the VTM's increase. The study finds that for scenario one and scenario two, there is a $64 \%$ increase in VTM's for second plant built versus the first plant constructed (Table 7). This calculation is done by summing the VTM miles for plant 2 for scenarios one and two $(5,434,636)$ and dividing by the sum of VTM miles from plant 1 for the two scenarios $(3,316,853)$. This change increases to $98 \%$ 
more VTM for the $3^{\text {rd }}$ built plant compared to the first built plant. The VTM increase for scenario three between plants is much less, which is attributed to less fuelshed overlap which results from the higher biofuel yield estimate that may represent the future state.

When compared to the established grain-based industry, the cellulosic biofuel industry is projected to generate 101 to $583 \%$ more VTM's per gallon of capacity. When weight is taken into account, the ton-miles per gallon of capacity are projected to be $4 \%$ to $255 \%$ higher than the grainbased ethanol for the cellulosic platforms.

\section{References}

Bain, R.L. "World Biofuels Assessment, Worldwide Biomass Potential: Technology Characterizations.” NREL/MP-510-42467, NREL, Golden, Colorado, 2007.

Brechbill, S.C. and W. E. Tyner. "The Economics of Biomass Collection, Transportation, and Supply to Indiana Cellulosic and Electrical Utility Facilities." Department of Agricultural Economics Working Paper 08-03: Purdue University, 2008.

Brechbill, S.C., W.E. Tyner, and K. E. Ileleji, "The Economics of Biomass Collection, Transportation, and Supply to Indiana Cellulosic and Electric Utility Facilities." Transition to a Bioeconomy: Risk, Infrastructure and Industry Evolution. Farm Foundation Conference, Berkeley, CA., 2008.

Federal Highway Administration. "Vehicle Travel Information System.” Indiana, 2009.

Geohack. http://toolserver.org/ geohack/ Accessed January 2008.

Indiana Department of Transportation. "FUNCTIONAL_CLASS_INDOTMODEL_IN: Functional Classification of Roadways" (from INDOT Statewide Travel Demand MODEL version 4, ISTDM4), 2004.

Indiana Department of Transportation. "INDOT Functional Class (FC) Colors.” 2007.

Khachatryan, H., E. L. Jessup, and K. Casavant. "Derivation of Crop Residue Feedstock Supply Curves Using Geographic Information Systems." Journal of the Transportation Research Forum 48 (1), (2009): 5-21.

Perkis, D., W. E. Tyner, P. Preckel, and S. C. Brechbill. "Spatial Optimization and Economies of Scale for Cellulose to Ethanol Facilities in Indiana." Transition to a Bioeconomy: Risk, Infrastructure and Industry Evolution. Farm Foundation Conference, Berkeley, CA., 2008.

Perlack, R. D., L. L. Wright, A. F. Turhollow, R. L. Graham, B. J. Stokes, and D.C. Erbach. "Biomass as Feedstock for a Bioenergy and Bioproducts Industry: The Technical Feasibility of a Billion-Ton Annual Supply.” 2005.

Quear, J. L. “The Impacts of Biofuel Expansion on Transportation and Logistics in Indiana.” Purdue University, West Lafayette, Indiana, 2008.

Renewable Fuels Association. "Industry Statistics.” 2009.

Trimac Consulting Services LTD. “Truck Traffic Changes in Grain Transportation.” 1999.

U.S. Census Bureau. "State and County QuickFacts.” 2009.

Yu, T. H. and C. Hart. "The 2006/07 Iowa Grain and Biofuel Study: A Survey Report.” Iowa State University, 2008. 
Cellulosic Biofuels Industry

\section{Acknowledgements}

This research was funded by a grant from Nextrans, an entity of the U.S. Department of Transportation.

Professor Wallace Tyner is an energy economist and James and Lois Ackerman Professor of Agricultural Economics at Purdue University. Tyner's research interests are in the area of energy, agriculture, and natural resource policy analysis and structural and sectoral adjustment in developing economies. He has published more than 200 professional papers in these areas including three books and more than 70 journal papers, abstracts, and book chapters. He has received national awards for his work in policy, his research, and quality of communication. In 2009 he received the Purdue College of Agriculture Outstanding Graduate Educator award.

Craig Rismiller received his M.S. degree from Purdue University and is now employed at Capital One. This paper is based on his M.S. research project. 